\title{
PSMG2 wt Allele
}

National Cancer Institute

\section{Source}

National Cancer Institute. PSMG2 wt Allele. NCI Thesaurus. Code C104900.

Human PSMG2 wild-type allele is located in the vicinity of 18p11.21 and is approximately $23 \mathrm{~kb}$ in length. This allele, which encodes proteasome assembly chaperone 2 protein, plays a role in promoting assembly of the $20 \mathrm{~S}$ proteasome. 